\title{
РОЗРОБКА ОФТАЛЬМОЛОГІЧНОГО ЛАЗЕРНОГО ПРИСТРОЮ
}

Богомолов М.Ф., доц, к.Т.н. nbogom@yahoo.com

Данилець М.О., студентка maryadanyleth@gmail.com

Кафедра біомедичної інженерії Національний технічний університет України “Київський політехнічний інститут імені Ігоря Сікорського”

Київ, Україна

\begin{abstract}
Реферат - Сучасна діагностика захворювань очного дна потребує застосування найбільи довериеного обладнання. Коло застосування лазерів в офтальмології дуже широке, а типи лазерних джерел-різноманітні. При цььому $і$ частка лазерних установок для офтальмологї серед загального промислового випуску лазерів досить велика. Ведеться активна робота по залученню джерел когерентного випромінювання з якісно новими характеристиками. Використання мультихвильового лазерного джерела розиирює коло можливих застосувань в лікуванні захворювань ока. Маючи можливість вибирати з декількох довжин лазерного випромінювання, щуо відрізняються за свойми характеристиками проникнення в тканини ока, мультихвильовий пристрій дозволяє фахівцям оптимізувати довжину хвилі, яка максимально поглинається цільовим хромофором і мінімально поглинається іниими хромофорами. В результаті забезпечується індивідуальне лазерне лікування з оптимальним клінічним результатом і мінімальними побічними ефектами. Тому актуальною є розробка багатофункціонального діагностичного та терапевтичного пристрою для лікування очних захворювань. У даній роботі представлено розроблені принципові схеми блоку накачки лазера та блоку живлення офтальмологічного пристрою.
\end{abstract}

Ключові слова: мультихвильове випромінювання, лазер, лазерна терапія, лазерна діагностика, офтальмологія, хоріоідея.

\section{I. ВСТУП}

Судинна патологія очей в даний час $є$ однією 3 основних причин слабкозорості, сліпоти й інвалідності органа зору [1]. Весь час тривають пошуки кращих способів лікування i спроби вдосконалити існуючі методики виконання лазерних процедур. Важливою областю застосування лазерного випромінювання є патології очного дна. При цьому, основним об'єктом впливу лазерного випромінювання стають оболонки, що формують багатошарову структуру очного дна: нейроепітелій і пігментний епітелій сітківки, судинна і білкова оболонки ока.

Альтернативою пошуку “ідеального" лазера $\epsilon$ створення комбінованих лазерних комплексів, до складу яких входить кілька випромінювачів з різними характеристиками.

У 80-ті роки минулого століття в результаті спільної роботи КБТМ, ГОІ ім. С.І. Вавилова і Загорського ОМЗ був створений i впроваджений в медичну практику передовий для того часу багатофункціональний мультихвильовий лазерний офтальмологічний комплекс "ЛИМАН-2", який працював на 4-х довжинах хвиль $(514,694,1060,1540$ нм).
Лазерний інфрачервоний (довжина хвилі випромінювання $\lambda=810$ нм) офтальмокоагулятор "АЛОД-02", розроблений спільно ТОВ "Алком Медика" та ГОІ ім. С.I.

Вавилова (Санкт-Петербург), знайшов широке застосування в клініках Росії та країн СНД.

Перша модульна мультихвильова лазерна система OcuLight Symphony (IRIDEX, США), поєднала в одному пристрої клінічну універсальність i зручність лазерів, що випромінюють на довжинах хвиль 532 нм і 810 нм, призначалася для лазерної коагуляції сітківки, транспупілярної термотерапії хоріоідальної неоваскуляризації, транссклеральної фотокоагуляції сітківки i циліарного тіла, лазерної трабекулопластики.

Російським підприємством ЗАТ "ОРІOH МЕДИК "спільно з ТОВ" АЛКОМ Медика " розроблений офтальмологічний лікувальнодіагностичний комплекс на основі щілинної лампи, оснащений мультихвильовим фотокоагулятором із застосуванням патернскануючого променя. Фотокоагулятор на довжинах хвиль 532 і 810 нм має можливість роботи на двох довжинах хвиль як по черзі, так 
i одночасно, 3 налаштуванням інтенсивності випромінювання кожної довжини хвилі [2].

\section{ІІ. РОЗРОБКА ПРИСТРОЮ}

У роботі [3] розроблено структурну схему універсального діагностично-лікувального пристрою для офтальмології (рис. 1) на основі щілинної лампи, 3 використанням мультихвильового лазерного джерела 3 можливістю роботи на декількох довжинах хвиль окремо або одночасно з налаштуванням інтенсивності кожної довжини хвилі, що розширює коло можливих застосувань. Дія приладу для діагностики та лікування судин сітківки ока базується на поєднанні дії декількох лазерних джерел: Nd: YAG-лазера 3 подвоєнням частоти, що випромінює на довжині хвилі 532 нм; криптонового лазера (Kr), який випромінює світло в жовтому і червоному діапазонах (568 нм і 647 нм), гелій-неонового (He-Ne) ЛГН-207А: працює на довжині хвилі 632.8 нм; іонного аргонового лазера з довжиною хвилі 488 або 514 нм [4].

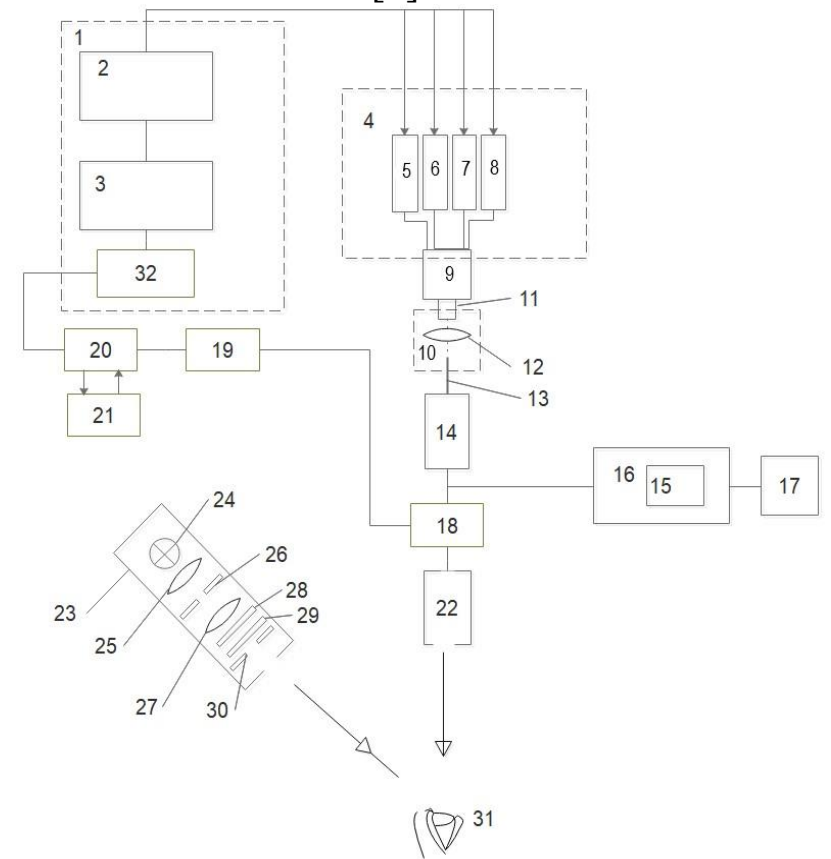

Рис. 1. Узагальнена структурна схема офтальмологічного пристрою: 1 - базовий блок, 2-блок керування, 3 - блок живлення, 4 - оптичний блок, 5-8 - лазерні випромінювачі, 9 - волоконнооптичний перетворювач, 10 - схема узгодження джерел випромінювання та світловода, 11 - оптичний роз'єм, 12 мікролінза, 13 - світловод, 14 - формуюча система, 15 - бінокуляр, 16 - щілинна лампа, 17 - екран, 18 - сенсор вимірювача доз лазерного випромінювання, 19 - вимірювач доз лазерного випромінювання, 20 - пристрій порівняння, 21 - задавач потужності лазерного випромінювання, 22 - скануюча система, 23 - освітлювач, 24 - лампа, 25 - лінза, 26 - вхідна щілина, 27 об’єктив, 28 - регулятор інтенсивності, 29 - оптичний фільтр, 30 вихідна щілина, 31 - око, 32 - мікропроцесор.
Розроблено принципову схему блоку живлення пристрою (рис.2). В таблиці 1 перелічено основні складові схеми.

Таблиця 1. Опис складових схеми блоку живлення пристрою

\begin{tabular}{|c|c|c|}
\hline $\begin{array}{l}\text { Номер } \\
\text { на схемі }\end{array}$ & Опис & Кількість \\
\hline \multicolumn{3}{|c|}{ Схема блоку живлення пристрою } \\
\hline & $\begin{array}{l}\text { Частина схеми, відповідальна } \\
\text { за випрямлення мережевої } \\
\text { напруги та їі подачу на першу } \\
\text { обмотку трансформатора. } \\
\text { Включає в себе конденсатори } \\
\text { фільтрів, діодний міст. }\end{array}$ & \\
\hline & 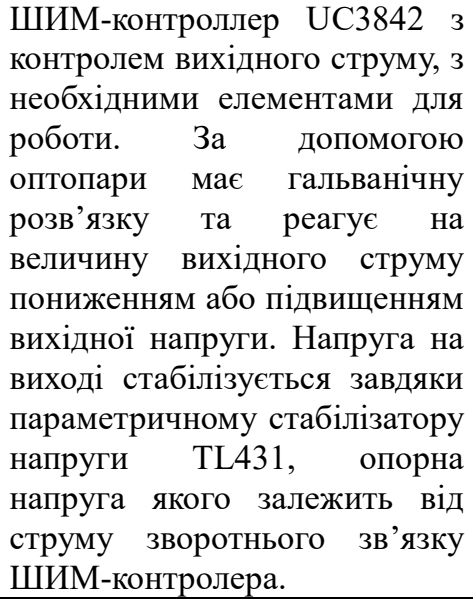 & \\
\hline & $\begin{array}{l}\text { Вихідна частина схеми, } \\
\text { містить конденсатори фільтрів } \\
\text { та котушку індуктивності для } \\
\text { зниження завад. }\end{array}$ & \\
\hline
\end{tabular}

Для створення блока живлення пристрою був обраний принцип побудови схем імпульсних блоків живлення, по топології зворотноходового перетворювача, що $є$ оптимальним варіантом для забезпечення необхідної потужності.

На ринку силових приладів представленно досить широкий асортимент електроніки для побудови імпульсних блоків живлення. Серцем будь-якого імпульсного блоку живлення $є$ ШИМ-контролер, який комутує силові ключі трансформатора. На даний час, однією $з$ найбільш вживаних на практиці мікросхем ШИМ-контролерів є мікросхеми серії UC38xx, які можуть отримувати живлення 3 мережевої напруги, так як мають вбудований параметричний стабілізатор на 34 В.

Різні серії ШИМ-контролерів відрізняються за максимальним робочим циклом, температурним діапазоном, пороговими рівнями внутрішніх тригерів. 


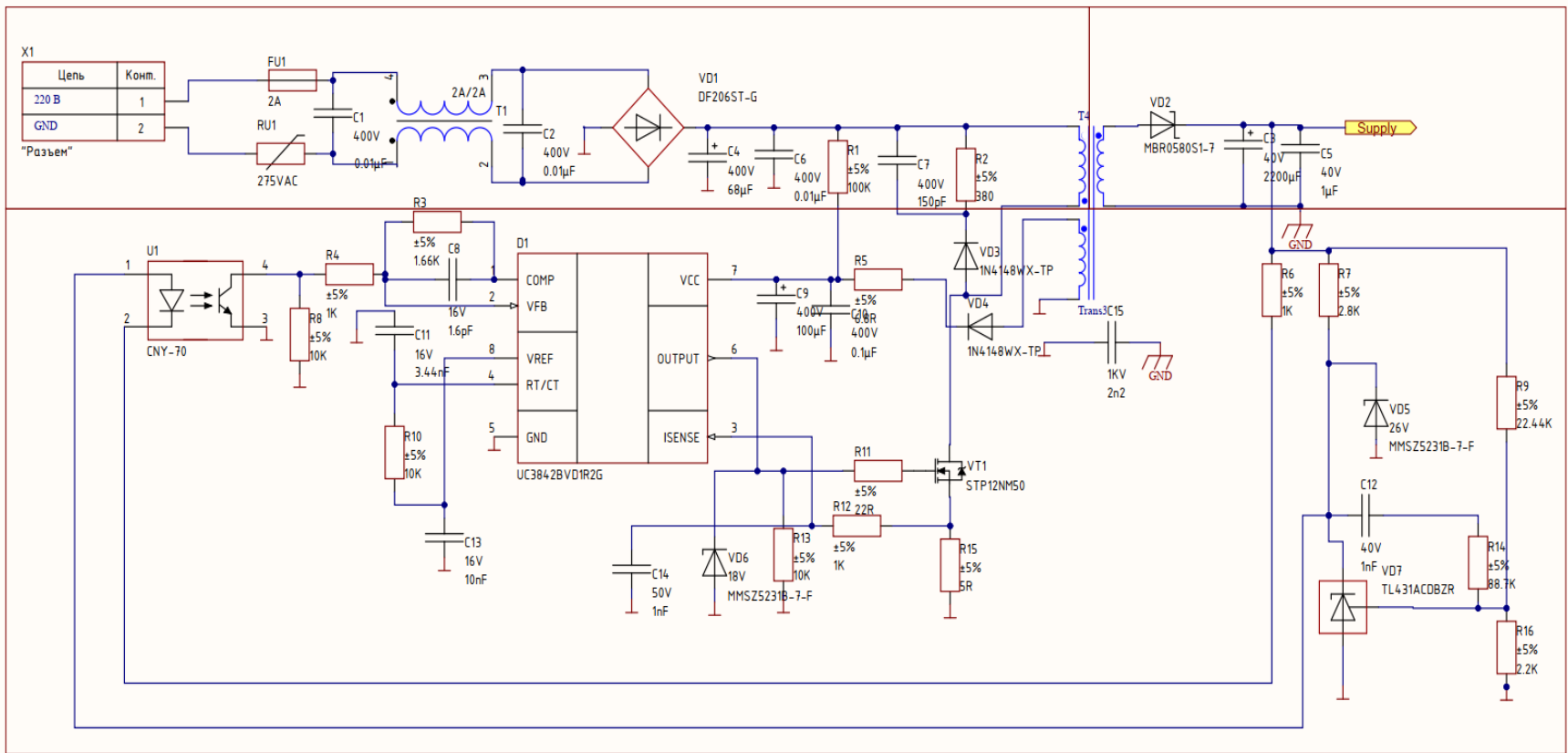

Рис. 2. Принципова схема блока живлення пристрою.

Для розроблюваного пристрою забезпечено можливіть регулювати скважність імпульсів від 0 до 100 відсотків, порогові рівні взято максимально можливими, оскільки подається живлення від 220 В (в момент запуску). До температурного діапазону серйозних вимог немає, тому обрано мікросхему UC3842.

Частоту роботи UC3842 розраховано згідно з їі частотною характеристикою (рис. 3):

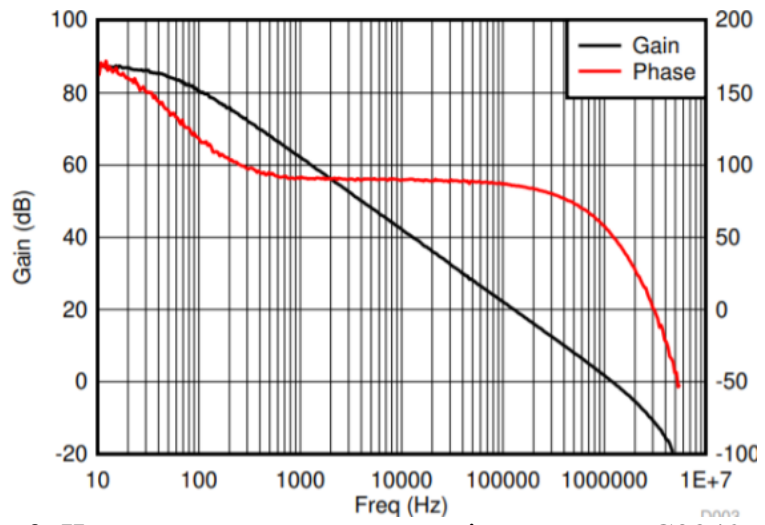

Рис. 3. Частотна характеристика мікросхеми UC3842 [6].

Достатньо типова частота 50 кГц є майже на 20 разів меншою ніж частота зрізу характеристики (рис. 3). Також, згідно характеристики, підібрано шунтуючий конденсатор задля усунення автоколивального режиму (у разі надходження завад або виходу приладу з ладу). Схема зворотнього зв'язку потребує гальванічної розв'язки за напругою. Для цього обрано оптопару CNY-70, що $\epsilon$ типовим рішенням. Розраховано чутливість оптопари та необхідні номінали резисторів за допомогою наступної характеристики (рис. 4):

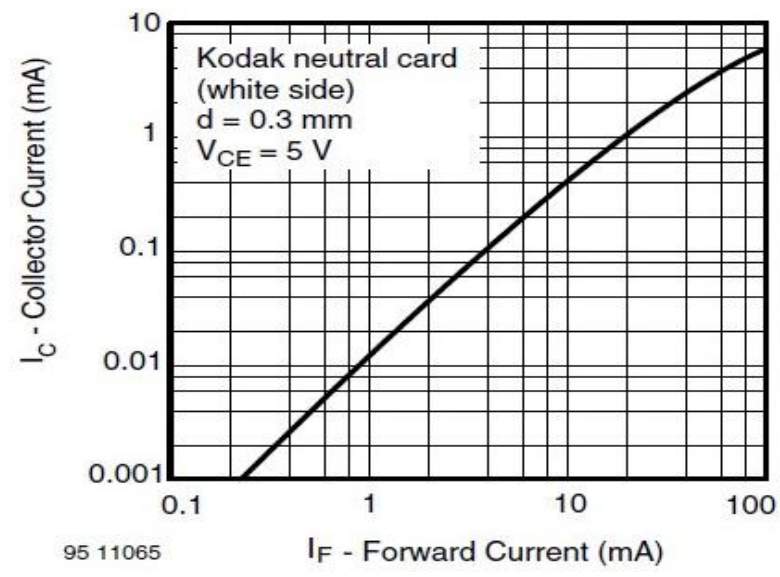

Рис. 4. Залежність струму колектора від струму фотодіода в оптопарі [6].

Для забезпечення допоміжної стабілізації вихідної напруги було використано параметричний стабілізатор TL431. Його функціональна схема представлена на рис. 5. 


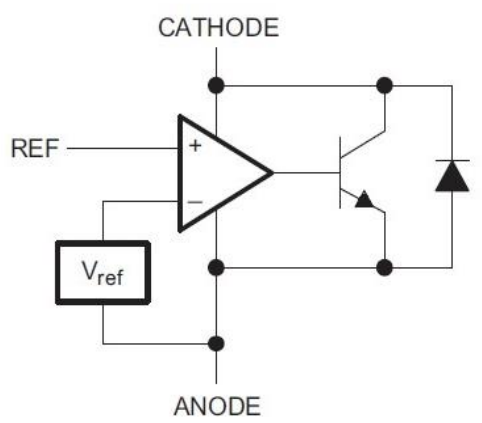

Рис. 5. Мікросхема TL431 [7].

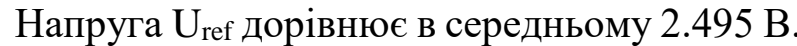
Згідно цього, регулюючи напругу на опорному вході, можна регулювати напругу стабілізації виходу, також ця схема може бути сигнальною, відносно вихідної напруги, відстежуючи їі рівень.

Розрахунок схеми почнемо з силового входу схеми, конденсатори вхідних та вихідних згладжуючих фільтрів якого розраховано згідно вимоги $R C \gg \frac{1}{f}$, де $f$ - це подвоєна частота у випадку двонапівперіодного випрямляча, або частота ШИМ для вихідної ланки. Так у даному випадку, при еквівалентному вхідному опорі 1.5 кОм, необхідна ємність становить 65 мкФ. Конденсатори, ємність яких становить 100 нФ використовуються як шунти для високочастотних завад. Аналогічно, конденсатор фільтру вихідного тракту буде рівний 2200 мкФ.

Стартова схема для мікросхеми ШИМ, складається з $R_{1} C_{9} C_{10}$. Необхідно зауважити, що ця ланка працює лише в стартовий момент, максимальний струм споживання при цьому складає згідно документації 500 мкА. Таким чином номінал резистора та конденсаторів підбирають таким чином щоб утримати необхідний стартовий струм. Номінал $R_{1}$ при цьому розраховано наступним чином:

$$
R_{v c c(\max )}=\frac{U_{i n(\min )}-U_{u c c(\max )}}{I_{u c c(\max )}+\left(Q_{g} \times f_{s w}\right)},
$$

де $U_{i n(\min )}$ - це мінімальне значення вхідної напруги $\left(280\right.$ В), $U_{v c c(\max )}$ - це максимальне значення напруги живлення мікросхеми (34 В), $I_{v c c(\max )}$ - це максималний стартовий струм мікросхеми (1 мA), $\mathrm{Qg}_{\mathrm{g}}$ - параметр, що визначає заряд затвору транзистора (28 нКл), $f_{s w}$ - частота роботи ШИМ (50кГц).

Таким чином, підставивши значення у формулу, отримуємо:

$$
\begin{aligned}
R_{v c c(\max )} & =\frac{280-34}{10^{-3}\left(28 \times 10^{-9} \times 50 \times 10^{3}\right)} \\
& \approx 100 \mathrm{\kappa OM.}
\end{aligned}
$$

Конденсатор $\mathrm{C}_{9}$ згідно рекомендаціям виробника має ємність 100 мкФ. Конденсатор $\mathrm{C}_{10}$ використовується як шунт для завад, його ємність 100 нФ.

Розрахунок снаберу на $\mathrm{R}_{2} \mathrm{C}_{7} \mathrm{VD}_{3}$. Снабер як елемент демпфування рекуперативних явищ потрібний для збереження силових ключів схеми. Ємність розраховано за наступною формулою:

$$
C_{\text {clamp }}=\frac{I \times t}{U} \approx 150 \Pi \Phi,
$$

де $I$ - максимальна величина струму в колі рекуперації (0.2 A), $t$ - час встановлення стану в силовому ключі $(300 \mathrm{Hc}), U-$ максимальна напруга до якої повинна заряджатись ємність (400 B).

Потужність розсіювання снаберу можна знайти як:

$$
P_{\text {clamp }}=\frac{f \times C_{\text {clamp }} \times U^{2}}{2} \approx 0.6 \mathrm{BT},
$$

де $f$ - частота комутації ключа (50 кГц).

Для визначення необхідного номіналу резистора снаберу, рораховано час відкритого стану ключа:

$$
T_{\text {on }}=\frac{D}{f}-t \approx 5.7 \times 10^{-6},
$$

де $D$ - параметр скважності імпульсів, за замовчуванням прийняли його рівним 0,3 .

Таким чином, за час рівний $5 R C$, повинен повністю відбутись перехідний процес, цей час повинен бути набагато менший, ніж $T_{o n}$, припустимо 5\% від часу відкритого стану ключа. Виходячи 3 цього оцінили номінал резистора:

$$
R_{\text {clamp }}=\frac{0.05 \times T_{\text {on }}}{5 \times C_{\text {clamp }}} \approx 380 \text { Ом. }
$$

Тепер повернемось до розрахунку часових параметрів схеми. Як було сказано раніше, частота ШИМ рівна 50 кГц, отже за цей параметр відповідають елементи $\mathrm{R}_{10} \mathrm{C}_{11}$. Розрахунок проведено за формулою:

$$
f=\frac{1.72}{R t \times C t} .
$$

Вона справедлива за умови, що $R t \geq 5$ кОм. Прийняли $R t=10$ кОм. Тоді, згідно формули, $C t$ $=3.44 \mathrm{H} \Phi$.

Таким чином, отримано частоту повторення імпульсів 50 кГц. 
Вивід токового захисту мікросхеми (ISENSE). Його призначення - запобігання короткого замикання в первинній та вторинній частинах схеми. Розрахунок компонентів доволі простий: $\mathrm{R}_{15} \epsilon$ перетворювачем струм-напруга, алгоритм роботи такий: коли струм у колі первинної обмотки перевищує граничний, спрацьовує вхід ISENSE мікросхеми, що призводить до відключення вихідного драйвера. Номінал визначено наступним чином:

$$
R_{15}=\frac{U_{t h}}{I_{t h}}
$$

де, $U_{t h}-$ порогова напруга для даної мікросхеми, становить 1 В. $I_{t h}-$ пороговий струм для даної схеми. При потужності первинної частини схеми 62 Вт, та при напрузі $310 \mathrm{~B}$, струм дорівнює $0.2 \mathrm{~A}$.

Таким чином:

$$
R_{15}=\frac{1}{0.2}=5 \text { Ом. }
$$

Компоненти $\mathrm{R}_{12} \mathrm{C}_{14}$ являють собою RCфільтр, необхідний для заземлення високочастотних завад.

Зворотня напруга похибки, подається на вхід $\mathrm{V}_{\mathrm{fb}}$ через схему негативного зворотнього зв'язку з частотною корекцією, на елементах $\mathrm{R}_{3} \mathrm{R}_{4} \mathrm{C}_{8}$. Згідно частоти, де зміщення фази рівне нулю, поставлено конденсатор, який робить коефіцієнт підсилення меншим за одиницю. Згідно означення імпеданса конденсатора, це:

$$
C=\frac{1}{w \times X_{c}}=\frac{1}{2 \times 3.1415 \times 10^{6} \times 100}=1.59 .
$$

Номінали резисторів зворотнього зв'язку встановлено згідно 3 необхідним коефіцієнтом підсилення. Для встановлення верхньої межі перемикання, ознайомимося 3 передаточною характеристикою оптопари. Струм фотодіода при 28 В на виході рівний 10 мА. Згідно цього, струм колектора дорівнює 0.4 мА.

Таким чином, падіння напруги на струмовому шунті оптопари R 13 дорівнює 4 В. Номінали резисторів зворотнього зв'язку інвертуючого підсилювача визначено 3 урахуванням того, що на позитивному вході компаратора присутній потенціал $2.5 \mathrm{~B}$, що $\epsilon$ тригерним рівнем по входу. Для коректної роботи схеми, необхідно щоб при 4 В напруги на вході компаратора, напруга на виході становила 0 В. Для цього розраховано рівність:

$$
\frac{\left(U_{\text {out }}-2.5\right)}{\left(U_{\text {in }}-2.5\right)}=-\frac{R_{16}}{R_{14}} \rightarrow \frac{2.5}{1.5}=\frac{R_{16}}{R_{14}}
$$

Прийняли $R_{14}$ рівним 1 кОм, тоді $R_{16}$ дорівнює 1.66 кОм.

Номінали компонентів компенсаційного $\mathrm{RC}$-ланцюга $\mathrm{C}_{19} R_{26} \quad$ встановлені згідно рекомендацій виробника мікросхеми.

\section{ІІІ. СПЕКТРАЛЬНІ ХАРАКТЕРИСТИКИ ОЧНИХ СЕРЕДОВИЩ}

Розуміння особливостей впливу лазерного випромінювання на тканини хоріоретинального комплексу дозволяє цілеспрямовано вибирати різну тривалість впливу, інтервал між імпульсами, потужність, діаметр плями, довжину хвилі при лікуванні різних захворювань i отримувати необхідний клінічний ефект [8]. Для вибору оптимального та безпечного для ока світлового випромінювання, що використовується в різних приладах, а також лазерного випромінювання для лікування очних захворювань необхідно знати характеристики поглинання очних середовищ. На рис. 6 наведені криві спектрального поглинання різними середовищами ока людини [9]. При виборі довжини хвилі лазерного випромінювання 3 метою впливу на тканини очного дна необхідно враховувати два основні фактори: пропускання випромінювання очними середовищами i його ефективне поглинання тканиною, яка обрана в якості об'єкта впливу. При цьому збудження суміжних областей повинно бути по можливості мінімальним. Прозорість оболонок передньої камери ока i склоподібного тіла визначається пропусканням води, що становить понад 90\% ваги тканини. 


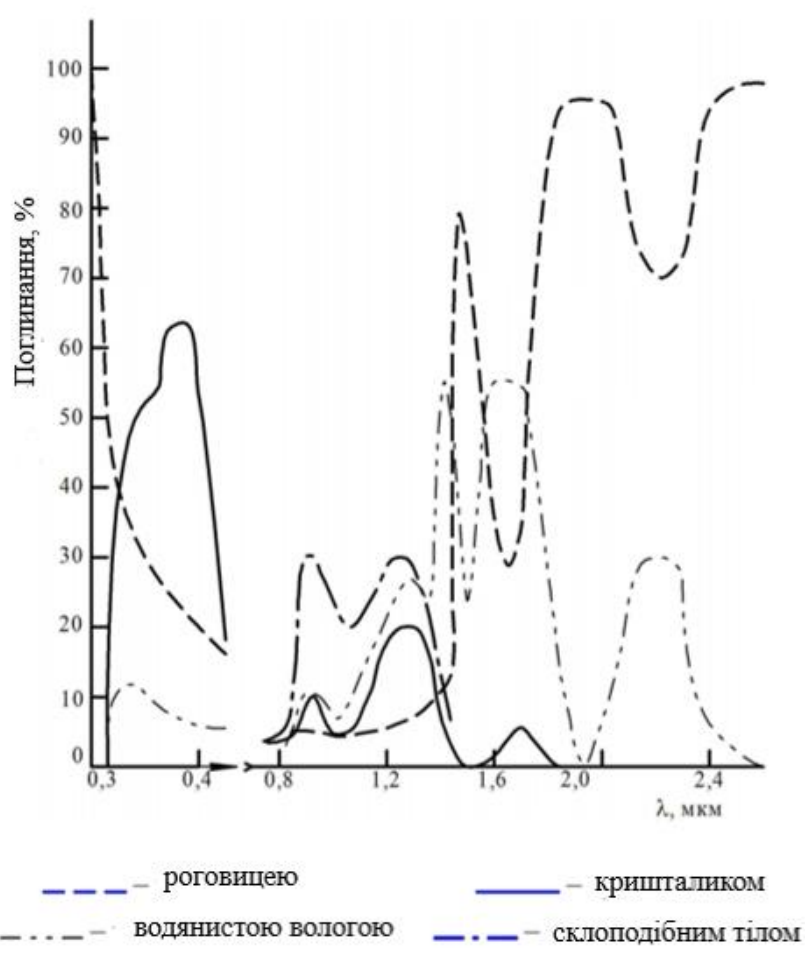

Рис. 6. Спектральне поглинання різними середовищами ока людини.

Сумарна крива поглинання прозорими оптичними середовищами ока представлена на рис. 7 (криві на рис. 4 і 5 зображені з розривом у видимій області спектра, оскільки поглинання оптичними середовищами ока в цій області мало).

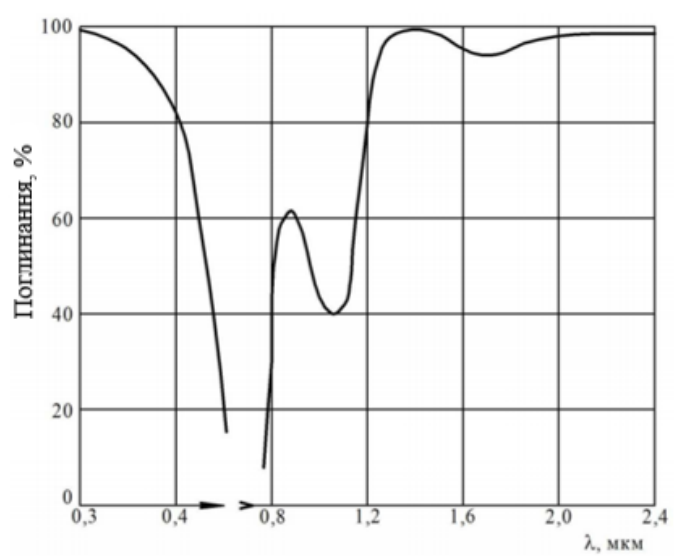

Рис. 7. Сумарне поглинання прозорими оптичними середовищами ока.

Оптичні середовища ока, поглинаючи частину падаючого світла у відповідності зі своїми спектральними характеристиками, значно послаблюють падаюче випромінювання i сітківки досягають в основному промені видимої і ближньої інфрачервоної області спектра. Оболонки i структурні елементи сітківки також по-різному взаємодіють 3 випромінюванням різних довжин хвиль. Пігментний епітелій і хоріоідея, наприклад, поглинають більше $70 \%$ синьо-зеленого випромінювання, а також досить ефективно червоне (близько 50\%), про що можна судити за графіком, представленим на рис. 8.

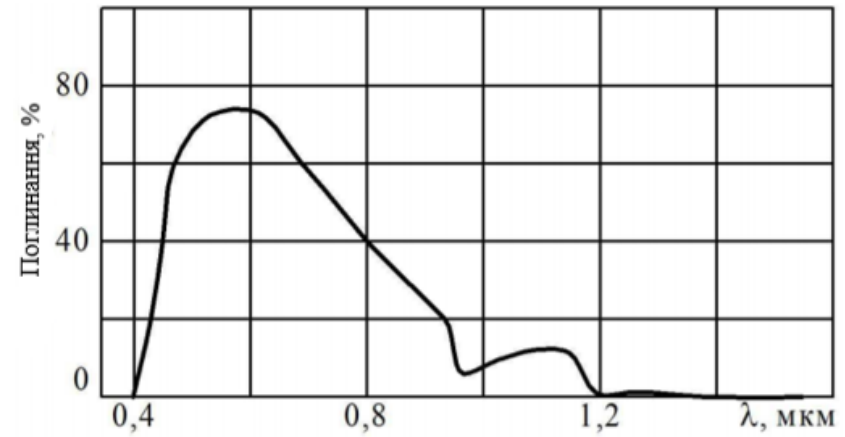

Рис. 8. Спектральне поглинання в пігментному епітелії сітківки і хоріоідеї ока людини.

Судини сітківки, що містять гемоглобін, найбільше поглинають випромінювання жовтозеленої частини спектра 3 довжиною хвилі 0,500,58 мкм і майже повністю відбивають червоне випромінювання. Нервові закінчення в макулярній області інтенсивно поглинають випромінювання синьо-зеленої частини спектру.

В цілому у видимій області спектра очні середовища досить прозорі - до сітківки доходить близько $\quad 80 \%$ видимого випромінювання. Колагенові волокна, з яких складаються рогівкові пластинки, що забезпечують 㣙 прозорість, мають подвійне променезаломлення. 3 віком i при різних захворюваннях поляризація рогівки зменшується. У кришталику подвійне променезаломлення, навпаки, з'являється тільки при його помутнінні. У нормі подвійне променезаломлення має також сітківка. Ці властивості очних середовищ використовуються як при дослідженні функції зору, так і при огляді структури очного дна [9].

Таким чином, лазерне випромінювання 3 довжиною хвилі від 480 до 1150 нм досягає сітківки 3 мінімальними втратами. Кришталик i рогівка мають менше пропускання в ближньому ультрафіолеті, що обумовлено поглинанням білковою складової речовини. Інфрачервона область спектра характеризується істотним поглинанням в очних середовищах. 3 цієї причини випромінювання 3 довжиною хвилі, що перевищує 1150 нм, може 
використовуватися для лазерних втручань на очному дні тільки ендоскопічно.

При впливі лазерного випромінювання на структури хоріоретинального комплексу визначальне значення має поглинання випромінювання пігментованими шарами i гемоглобіном крові. Основним поглинаючим елементом пігментного епітелію $є$ меланін, який сконцентрований в крейдо-протеїнових гранулах, розміром близько 1 мкм [8]. 3 ростом довжини хвилі, поглинання випромінювання меланіном швидко слабшає. Найбільш привабливою 3 точки зору ефективності лазерного впливу на структури хоріоретинального комплексу $\epsilon$ синьо-жовта область спектра. Іншим компонентом біотканин, в значній мірі схильним до дії випромінювання, є гемоглобін. 3 ходу кривої на рис. 9 можна зробити висновок, що зі зменшенням довжини хвилі поглинання випромінювання гемоглобіном посилюється.

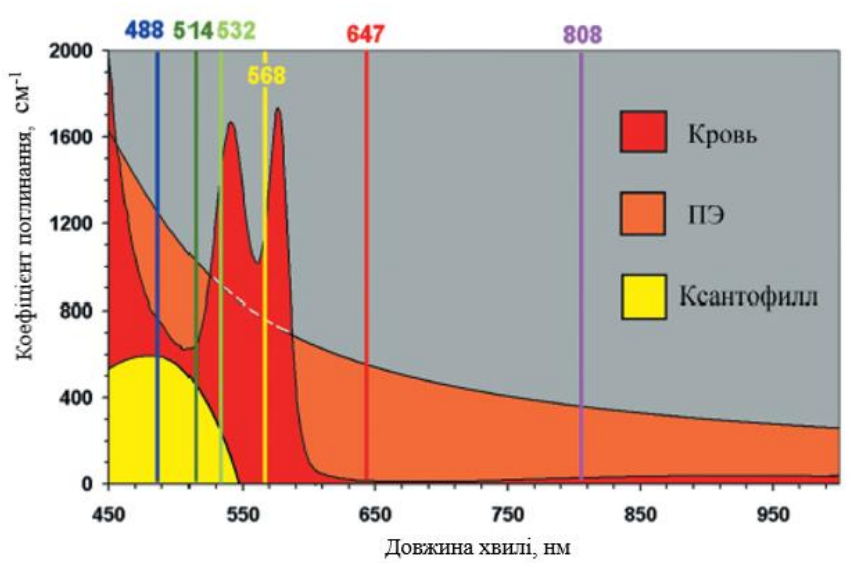

Рис. 9. Спектральні характеристики поглинання крові (гемоглобін), ПЕ (меланін) і пігментів макулярної області (лютеїн, зеаксантин) [8].

Найвиразніше ця залежність проявляється в синій області спектра. Криптоновий лазер, що генерує на довжині хвилі 647 нм, становить інтерес для проведення лазерних аплікацій в макулярній області, оскільки його випромінювання активно поглинається гранулами меланіну i практично не поглинається гемоглобіном i ксантофільним пігментом, присутнім у сітківці в області жовтої плями [8]. При втручаннях в макулярній області, наприклад, синьо-зеленим випромінюванням аргонового лазера 3 генерацією на 488 нм і 514 нм відзначається виділення потужності у внутрішньому i зовнішньому плексиформних шарах сітківки, що містять ксантофільний пігмент, тоді як відфільтроване випромінювання аргонового лазера 514 нм і випромінювання криптонового лазера 647 нм впливає на пігментний епітелій і судинну оболонку, не зачіпаючи шари сітківки. Великий інтерес в офтальмології представляють лазерні джерела на барвниках, використання яких дозволяє здійснювати перебудову довжини хвилі в межах всього видимого діапазону. Так, зміна довжини хвилі від 600 нм до 577 нм відповідає переходу від майже повного пропускання випромінювання гемоглобіном крові до піку поглинання. Одним 3 перспективних напрямків в області лазерних методів лікування в офтальмології $\epsilon$ застосування комбінованого впливу випромінювання 3 довжинами хвиль 532 нм і 1064 нм, що забезпечується одним твердотільним YAG: $\mathrm{Nd}$ - лазером з частковим перетворенням потужності в 2-гу гармоніку. Зміна пропорції між компонентами випромінювання дозволяє варіювати глибину його проникнення в структури хоріоретинального комплексу $[9,11]$.

\section{IV. ВИСНОВКИ}

Коло застосувань лазерів в офтальмології дуже широке, а типи лазерних джерел різноманітні. При цьому частка лазерних установок для офтальмології серед загального промислового випуску лазерів досить велика. Спостерігається стійка тенденція щодо вдосконалення i ускладнення існуючих лазерних офтальмологічних приладів. Застосовують найрізноманітніші моделі лазерних установок, що розрізняються як спектральним діапазоном довжин хвиль, так і режимом впливу на тканини органа зору.

Перевагами, які характерні для блоку живлення, розробленого в даній роботі, $\epsilon$ високий ККД (92-95\%), відносно малі розміри блоку живлення, менший нагрів елементів схеми. Проте слід зазначити і певні недоліки: високочастотні завади, які можуть виникати в процесі роботи та наявність критичних компонентів, при виході з ладу яких прилад стає непрацездатним.

Мультихвильовий пристрій, який працює на декількох довжинах хвиль, дозволить одночасно здійснювати обстеження пацієнтів i, при необхідності, проводити операції або терапевтичні процедури для широкої області 
патологій судинної оболонки очного дна [3]. Пропонується забезпечити блок керування мікропроцесором для дистанційного управління та розширення функціональних можливостей обробки даних.

\section{ПЕРЕЛІК ПОСИЛАНЬ}

Мирзабекова К. А. Метод лазеркоагуляции в лечении окклюзий вен сетчатки / К. А. Мирзабекова // Офтальмология / К. А. Мирзабекова. - Москва, 2015. - С. 33-38.

[1] Мультиволновой лазерный офтальмокоагулятор / [Л. Н. Пантелеев, Ю. С. Астахов, А. А. Иванов та ін.] // Оптический журнал / [Л. Н. Пантелеев, Ю. С. Астахов, А. А. Иванов та ін.].Санкт-Петербург, 2014. - (2). - С. 55-61.

[2] Богомолов М. Ф. Мультихвильовий діагностичнолікувальний пристрій для офтальмології / М. Ф. Богомолов, М. О. Данилець // Біомедична інженерія і технологія / М. Ф. Богомолов, М. О. Данилець. - Київ, 2020. DOI: https://doi.org/10.20535/2617-8974.2020.4

[3] Данилець М. О. Універсальний діагностичнолікувальний пристрій для офтальмології / М. О. Данилець, М. Ф. Богомолов // Міжнародна науково-технічна конференція "Радіотехнічні поля, сигнали, апарати та системи" / М. О. Данилець, М. Ф. Богомолов. - Київ: Політехніка, 2020. - С. 159161.
[4] UCx84x Current-Mode PWM Controllers [Електронний ресурс] - Режим доступу до ресурсу: https://www.ti.com/lit/ds/symlink/uc2845.pdf?ts=1614861020596 \&ref_url=https $\% 253 \mathrm{~A} \% 252 \mathrm{~F} \% 252 \mathrm{Fwww}$.google.com $\% 252 \mathrm{~F}$.

[5] Reflective Optical Sensor with Transistor Output [Електронний ресурс] - Режим доступу до ресурсу: https://www.vishay.com/docs/84285/vent2020.pdf

[6] TL431 / TL432 Precision Programmable Reference [Електронний ресурс] - Режим доступу до ресурсу: https://www.ti.com/lit/ds/symlink/t1431.pdf?ts=1614864700309\&re f_url=https $\% 253 \mathrm{~A} \% 252 \mathrm{~F} \% 252 \mathrm{Fwww}$.google.com $\% 252 \mathrm{~F}$.

[7] Селективное действие лазерных импульсов на ретинальный пигментный эпителий. Физические основы. / Г.

И.Желтов, Г. С. Романов, О. Г. Романов, Е. В. Иванова // Новое в офтальмологии / Г. И.Желтов, Г. С. Романов, О. Г. Романов, Е. В. Иванова. - Москва: Офтальмология, 2012. - С. 37.

[8] Хацевич Т. Н. Медицинские оптические приборы. Физиологическая оптика: учеб. пособие / Т. Н. Хацевич. Новоосибирск: СГГА, 2010. - 135 с. - (3-е изд., испр. и доп.).

[9] Вопросы лазерной офтальмологии. Виды современных лазерных систем в офтальмологии для коррекции зрения - плюсы и минусы [Електронний ресурс]. - 2015. Режим доступу до ресурсу: https://eardoc.ru/cough/voprosylazernoi-oftalmologii-vidy-sovremennyh-lazernyh/.

[10] Применение лазеров в офтальмологии: учебное пособие для врачей-интернов специальности "Офтальмология" / Н. Г.Завгородня, Б. С. Безуглый, М. Б. Безуглый, Л. Э. Саржевская. - Запорожье: ЗГМУ, 2015. - 79 с. 


\title{
РАЗРАБОТКА ОФТАЛЬМОЛОГИЧЕСКОГО ЛАЗЕРНОГО УСТРОЙСТВА
}

Богомолов М.Ф., дои, к.т.н. nbogom@yahoo.com

Данилец М.О., студентка maryadanyleth@gmail.com

Кафедра биомедицинской инженерии Национальный технический университет Украины “Киевский политехнический институт имени Игоря Сикорского”

Киев, Украина

Реферат - Современная диагностика заболеваний глазного дна требует применения наиболее совершенного оборудования. Круг применения лазеров в офтальмологии очень иирок, а типы лазерных источников - разнообразны. При этом и доля лазерных установок для офтальмологии среди общего промышленного выпуска лазеров достаточно велика. Ведется активная работа по привлечению источников когерентного излучения с качественно новыми характеристиками. Использование мультиволнового лазерного источника расширяет круг возможных применений в лечении заболеваний глаз. Имея возможность выбирать из нескольких длин лазерного излучения, отличающихся по своим характеристикам проникновения в ткани глаза, мультиволновое устройство позволяет специалистам оптимизировать длину волны, которая максимально поглощается целевым хромофором, и 8 то же время минимально поглощается другими хромофорами. В результате обеспечивается индивидуальное лазерное лечение с оптимальным клиническим результатом и минимальныли побочными эффектами. Поэтому актуальной является разработка многофункиионального диагностического и терапевтического устройства для лечения глазных заболеваний. В данной работе представлены разработанные принципиальные схемы блока накачки лазера и блока питания офтальмологического устройства. Ключевые слова: мультиволновое излучение, лазер, лазерная терапия, лазерная диагностика, офтальмология, хориоидея.

UDC 535.338; 621.35; 541.13

\section{DEVELOPMENT OF OPHTHALMIC LASER DEVICE}

Bogomolov M. F., Associate Professor, Ph.D.. nbogom@yahoo.com

Danylets M.O., student maryadanyleth@gmail.com

Department of Biomedical Engineering National Technical University of Ukraine "Igor Sikorsky Kyiv Polytechnic Institute"

Kiev, Ukraine

\begin{abstract}
Modern diagnostics of fundus diseases requires the use of the most advanced equipment. The range of application of lasers in ophthalmology is very wide, and the types of laser sources are diverse. Moreover, the share of lasers for ophthalmology among the total industrial production of lasers is quite large. Active work is underway to attract sources of coherent radiation with qualitatively new characteristics. The use of a multi-wavelength laser source expands the range of possible applications in the treatment of eye diseases. With the ability to choose from several laser radiation lengths that differ in their characteristics of penetration into the tissues of the eye, the multiwave device allows professionals to optimize the wavelength that is maximally absorbed by the target chromophore, and at the same time is minimally absorbed by other chromophores. The result is a customized laser treatment with optimal clinical results and minimal side effects. Therefore, the development of a multifunctional diagnostic and therapeutic device for the treatment of eye diseases is urgent. This paper presents the developed schematic diagrams of a laser pumping unit and a power supply unit for an ophthalmic device.
\end{abstract}

Keywords: multiwave radiation, laser, laser therapy, laser diagnostics, ophthalmology, choroid. 